\title{
GLACIER SLIDING AT SUBFREEZING TEMPERATURES
}

\author{
By R. L. Shreve
}

(Department of Earth and Space Sciences, University of California, Los Angeles, California 90024, U.S.A.)

\begin{abstract}
Aвstract. Nye's theory of glacier sliding, when modified to incorporate Gilpin's model of the liquid layer adjacent to foreign solids in ice, predicts non-zero sliding speeds at subfreezing temperatures. Although the predicted speeds are too small to affect glacier motion or even to be observed readily, the total distance of sliding of large glaciers should be adequate to produce bedrock striations. Dissolved solutes in the liquid layer increase the sliding speeds slightly. At temperatures below about $-1{ }^{\circ} \mathrm{C}, 90 \%$ of the drag comes from the part of the bed-roughness spectrum at wavelengths between 0.2 and $20 \mathrm{~mm}$ regardless of solute concentration. If no more basal ice melts than refreezes (as in a cold glacier), the average liquid-layer thickness and, concomitantly, the sliding speed for given drag and roughness are governed by the ambient temperature. With net melting (as in a temperate glacier), on the other hand, they are governed by the rate of escape of the excess water and no conflict arises between the thickness requirement for run-off water flow and that for regelation water flow. Thus, the proper distinction is not between temperate and cold, but between net melting and no net melting. The theory applies to both cases.
\end{abstract}

RÉsumé. Glissement des glaciers à des températures inférieures au point de fusion. La théorie de Nye pour le glissement des glaciers, modifiée par l'incorporation du modèle de Gilpin d'un film liquide le long des inclusions solides dans la glace prévoit des vitesses de glissement non nulles à des températures négatives. Bien que les vitesses prévues soient trop faibles pour affecter le mouvement du glacier ou mème pour être facilement observables, la longneur totale de glissement des grands glaciers pourrait être suffisante pour produire des stries sur le lit rocheux. Des produits dissous dans le film liquide accroissent légèrement les vitesses de glissement. $\mathrm{A}$ des températures inférieures à $-1{ }^{\circ} \mathrm{C}, 90 \%$ de la traînée vient de la partie du spectre de rugosité du lit correspondant à des longueurs d'onde entre 0,2 et $20 \mathrm{~mm}$ quelle que soit la concentration des solutions. S'il ne fond pas plus de glace basale qu'il n'en regèle (cas d'un glacier froid), l'épaisseur moyenne du film d'eau liquide à la base, et donc la vitesse de glissement pour une trainée et une rugosité donnée, sont réglées par la température ambiante. Quand il y

\section{INTRODUCTION}

Regelation at subfreezing temperatures

At the moment, glaciologists are almost unanimous in the view that glacier sliding can occur only where the basal ice is at the melting temperature, and not where it is sub-freezing (Paterson, 1981, p. 112), because pressure melting and regelation are necessary for slip past the smallest-scale elements of the bed roughness (Nye, 1970, p. 390). The direct field observations generally cited as confirmation, however, namely those of Goldthwait (1960) and Hilty (1960, p. A3) carried out in a tunnel under an ice cliff in Greenland (basal ice temperature $-11^{\circ} \mathrm{C}$ ) and those of Holdsworth and Bull (1970, p. 206) in one under Meserve Glacier in Antarctica $\left(-18^{\circ} \mathrm{C}\right)$, at best show only that the slip is very small compared to what it would be at the melting temperature. Moreover, indirect evidence indicates that sliding at subfreezing temperatures might be possible, albeit slow. The migration of included solid particles in subfreezing ice under a temperature gradient (Hoekstra and Miller, 1967; Römkens and Miller, 1973) points strongly to the presence of a liquid or liquid-like layer surrounding such particles, similar to the layer on sub-freezing free ice surfaces proposed by Faraday (1850), argued by Weyl (1951) and Fletcher (1962), and demonstrated by Nakaya and Matsumoto (1953), Jellinek (1967), and others. The regelation of ice well below the pressure-melting temperature behind wires pulled transversely through it, as demonstrated by Telford and Turner (1963) and con- a d'excès de fusion (cas d'un glacier tempéré), au contraire, la régulation se fait par la vitesse à laquelle s'échappe l'eau en excès et il n'y a pas de conflit entre l'épaisseur de glace requise pour l'écoulement de l'émissaire et celle nécessaire pour le regel de l'eau écoulée. Dès lors la véritable distinction à faire n'est pas entre glaciers tempérés et froids mais entre glaciers à excès de fusion et ceux à déficit de fusion. La théorie s'applique aux deux cas.

Zusammenfassung. Gletschergleiten bei Temperaturen unter dem Gefrierpunkt. Nye's Theorie des Gletschergleitens, modifiziert durch den Einbau von Gilpin's Modell der flüssigen Schicht in der Umgebung von Fremdkörpern im Eis, lässt nicht-verschwindende Gleitgeschwindigkeiten bei Temperaturen unter dem Gefrierpunkt erwarten. Obwhol die zu erwartenden Geschwindigkeiten zu klein sind, um die Gletscherbewegung zu beeinflussen oder auch nur fesstellbar zu sein, sollte doch die gesamte Gleitstrecke grosser Gletscher ausreichen, um Riefen am Untergrund zu erzeugen. Gelöste Bestandteile in der Flüssigkeitsschicht erhöhen die Gleitgeschwindigkeit geringfügig. Bei temperaturen unter etwa $-1^{\circ} \mathrm{C}$ kommen $90 \%$ der Hemmkraft aus jenem Teil der Bettrauhigkeit, deren Wellenlänge im Gesamtspektrum zwischen 0,2 und $20 \mathrm{~mm}$ liegt, - ohne Berücksichtigung der Lösungskonzentration. Wenn nicht mehr Eis am Untergrund schmilzt als wiedergefriert (wie in einem kalten Gletscher), wird die mittlere Dicke der Wasserschicht am Untergrund und damit die Gleitgeschwindigkeit bei gegebener Reibung und Rauhigkeit durch die Temperatur der Umgebung bestimmt. Wenn andrerseits ein Schmelzwasserüberschuss besteht (wie in einem temperierten Gletscher), werden diese Werte durch die Abflussrate des überschüssigen Wassers geregelt. Zwischen der erforderlichen Dicke für den Abfluss und der des Wasserflusses bei Regelation tritt kein Widerspruch auf. Eine Unterscheidung sollte daher nicht zwischen temperiert und kalt, sondern zwischen Uberschuss und Nicht-Überschuss an Schmelzwasser getroffen werden. Die Theorie ist auf beide Fälle anwendbar.

firmed by Gilpin (1980), suggests even more compellingly that sliding at sub-freezing temperatures might be possible.

Telford and Turner (1963) used $0.45 \mathrm{~mm}$ diameter steel wires under a driving stress (as defined by Drake and Shreve, 1973, p. 55) of about $3 \mathrm{MPa}$ (30 bar). Speeds ranged from $160 \mathrm{~mm} \mathrm{a}^{-1}$ at $-3.5^{\circ} \mathrm{C}$ to $800 \mathrm{~mm} \mathrm{a} \mathrm{a}^{-1}$ at $-0.7^{\circ} \mathrm{C}$. A $50 \%$ increase in driving stress caused a three-fold increase in speed which, in the light of the high driving stress, suggests that plastic flow of the ice may have been significant. Other evidence on this point, however, is at best equivocal. The apparent activation energy calculated from the temperature dependence was $350 \mathrm{~kJ} \mathrm{~mol}^{-1}$ ( $\mathrm{re}$ calculated from the data presented), which is about twice the mean activation energy found by Mellor and Testa (1969, p. 135) for secondary creep of polycrystalline ice in the same temperature range. Al so, passage of the wire through a very thin gold foil embedded in the ice observably displaced it over a width about $40 \%$ greater than the diameter of the wire. Thus, Telford and Turner's quantitative results probably were affected by plastic flow. Nevertheless, their pioneering experiments demonstrated the existence of regelation at sub-freezing temperatures.

Gilpin (1980) used 0.0127 to $0.059 \mathrm{~mm}$ diameter tungsten wire under driving stresses from 0.27 to $0.68 \mathrm{MPa}$ ( 3 to $7 \mathrm{bar}$ ), $0.076 \mathrm{~mm}$ diameter Chromel (nominally $90 \% \mathrm{Ni}, 10 \% \mathrm{Cr}$ ) wire under $0.28 \mathrm{MPa}$ ( $3 \mathrm{bar}$ ), and 0.127 to $0.381 \mathrm{~mm}$ Constantan (nominally $55 \% \mathrm{Cu}$, $45 \% \mathrm{Ni}$ ) wire under 0.04 to $0.20 \mathrm{MPa}$ ( 0.4 to 2 bar). Speeds ranged from $1.3 \mathrm{~mm} \mathrm{a}^{-1}$ for $0.0127 \mathrm{~mm}$ diameter 
tungsten wire under $0.68 \mathrm{MPa}$ at $-35^{\circ} \mathrm{C}$ to $40 \mathrm{~mm} \mathrm{a}$ for $0.381 \mathrm{~mm}$ diameter Constantan wire under $0.04 \mathrm{MPa}$ at $-0.006^{\circ} \mathrm{C}$ (Gilpin, 1980 , p. 443 , fig. 8, using p. 442, eq. 18). For comparison, the lowest speeds observed by Drake and Shreve (1973, p. 56-58) at $0^{\circ} \mathrm{C}$ (blocks immersed in melt water and crushed ice) were around $160 \mathrm{~mm} \mathrm{a}^{-1}$. At constant temperatures the speeds increased linearly as the driving stress increased (Gilpin, 1980, p. 443, fig. 7); hence, plastic flow of the ice probably was insignificant. Thus, the experiments of Gilpin not only confirmed the existence of regelation at sub-freezing temperatures but also supplied detailed quantitative information on its rate.

Essentials of Gilpin's model

Gilpin undertook his experiments to test a model of the liquid-like layer adjacent to foreign solids in sub-freezing ice that he had proposed the previous year. The essential idea of the model (Gilpin, 1979, p. 238) is that the foreign solids attract adjacent water, which lowers its chemical potential by an amount assumed inversely proportional to some power $\alpha$ of the distance $y$ from the interface. The attraction causes an excess of pressure near the interface which in a thin, planar layer of uniform thickness is given by

$p_{W}(y)=p+\left(\frac{\rho_{w}}{\rho_{i}}-1\right) \frac{b}{c}\left(y^{-\alpha}-h^{-\alpha}\right)$

(derived from Gilpin, 1979, p. 239, eq. 5), where $p=p_{w}(h)$ is the pressure at the outer surface of the layer, $\rho_{W}$ and $\rho_{j}$ are the densities of water and ice, $C$ is the rate of decrease of melting temperature with pressure (from the Clapeyron equation), and b and $\alpha$ are experimentally determined constants. The gradient in the chemical potential makes equilibrium between water and ice at the outer surface dependent upon the layer thickness; thus, the pressure-melting temperature $\theta$ and pressure $\rho$ are related by

$$
\theta-\theta_{P M}=-C(p-p P M)-b h^{-\alpha}
$$

(derived from Gilpin, 1979, p. 239, eq. 11), where OPM is the melting temperature at pressure PPM of ice in contact with an infinitely thick water layer (such as $0^{\circ} \mathrm{C}$ at $1 \mathrm{~atm}$, or $0.1013 \mathrm{MPa}$, for example); that is, $\Theta_{P M}$ is the nominal melting temperature at pressure ppM.

From his regelation experiments Gilpin (1980, p. 445,446$)$ found $\alpha=2.4$ and $b=20 \mathrm{~nm}^{2} 4^{\circ} \mathrm{C}$ for the three metals used, in agreement with the results of nuclear magnetic resonance (n.m.r.) measurements made by Barer and others (1977) of the amount of unfrozen water in ice containing dispersed fine silica (Aerosil) particles. Below about $-15^{\circ} \mathrm{C}$ the points based on his measurements deviated from the fitted relationship, whereas the n.m.r. data did not, a discrepancy he attributed (Gilpin, 1980, p. 445) to excess water viscosity due to the extreme thinness of the liquid layer at the lower temperatures. It appears, however, that the discrepancy may actually be due to the formula he used to extrapolate the viscosity to the lower temperatures, which was a second-degree polynomial fitted to the viscosity data for water between -10 and $+10^{\circ} \mathrm{C}$ (Gilpin, 1980 , p. 444 ). From -10 to $-24^{\circ} \mathrm{C}$ it gives values which are increasingly lower than the measured values which Hallett (1963, p. 1049) determined using $0.2 \mathrm{~mm}$ diameter glass capillary tubes, the difference reaching about $24 \%$ at $-24^{\circ} \mathrm{C}$. An alternative formula,

Viscosity $(\mathrm{mPa} s)=1.79\left(\frac{55.8}{55.8+\text { Temperature }\left({ }^{\circ} \mathrm{C}\right)}\right)^{2}$, root-mean-square error of $0.5 \%$ and a maximum error of about $1.1 \%$. When extrapolated to higher temperatures, it gives values increasingly too $10 \mathrm{w}$, but the deviation is only $1.6 \%$ at $+10^{\circ} \mathrm{C}$ and $3.5 \%$ at $+20^{\circ} \mathrm{C}$. When extrapolated to $-35^{\circ} \mathrm{C}$, it gives a value of $12.9 \mathrm{mPa} s$ (whereas Gilpin's formula gives only $5.9 \mathrm{mPa}$ s). Inasmuch as this value eliminates the discrepancy between the regelation experiments and the n.m.r. measurements at the lower temperatures, it appears permissible to apply Gilpin's model and constants to ice in contact with silica and hence, with considerable confidence, with rock.

\section{SLIDING SPEED}

\section{Modification of $\mathrm{Nye}^{\prime} \mathrm{s}$ theory}

Clearly, Weertman's $(1957,1964)$ model of glacier sliding applies even at sub-freezing temperatures, inasmuch as all its basic assumptions are satisfied (at least down to $-35^{\circ} \mathrm{C}$ ): a thin basal water layer, pressure melting and regelation, and plastic deformation of the ice. To estimate the magnitude of the sliding speed it suffices to modify the theory of Nye (1969, 1970), which approximates the basal ice as a Newtonian viscous fluid, rather than that of Kamb (1970), which takes into some account its actual power-law rheology, or that of Lliboutry (1968), which includes subglacial cavitation. Hence, except as stated, the derivation that follows makes the same assumptions and uses the same notation as Nye's theory.

From Equation (1b) Nye's Fourier-transformed relationship between boundary temperature and pressure (1969, p. 449, unnumbered equation preceding eq. 2) becomes

$$
\bar{\theta}(k)=-c \bar{p}_{n}(k)-b\left(\overline{h^{-\alpha}-h_{m}^{-\alpha}}\right),
$$

where $h_{m}{ }^{-\alpha}$ is the value of $h^{-\alpha}$ averaged over the glacier bed, the overbars denote Fourier transforms, and $k$, the argument of the Fourier-transformed functions, is the wave number. The quantity $h_{m}$ is the thickness the water layer would have if the bed were planar. Thus, the unperturbed thickness is always finite, whereas in Nye's theory (Nye, 1969, p. 447) it is zero, which, amongst other things, obviates the difficulty with negative liquid-layer thicknesses pointed out and discussed by Nye (1973[a]). This is a fundamental difference: Nye's theory cannot be recovered simply by setting b to zero in the modified equations.

In terms of the bed-perturbation parameter $\varepsilon$,

$h^{-\alpha}=h_{m}^{-\alpha}\left(1+\varepsilon \delta_{i}+\varepsilon^{2} \delta_{2}+\ldots\right)$.

Mathematically, $\varepsilon$ has to be small enough to ensure the convergence of the series. Physically, however, it approximates the slopes of the bed roughness. Thus, for application $\delta_{1}, \delta_{2}, \ldots$, have to be small relative to $1 / \varepsilon$.

Nye's relationship from regelation physics (Nye, 1969 , p. 452, eq. 25) then becomes, letting $K$ be the mean thermal conductivity of ice and rock,

$\bar{p}_{1}(k)=-\frac{L \bar{W}(k)}{2 c k|k|}-\frac{b h_{m}-\alpha \bar{\delta}_{1}(k)}{c}$

on $z=0$, the mean elevation of the bed.

The new feature is the second term in the righthand side of Equation (4). It forces explicit consideration of the flow in the liquid layer, which in Nye's theory was unnecessary. Let $q_{w}$ be the mass rate of flow in the liquid layer. Then conservation of mass requires

$$
\rho j w_{n}=-d q_{w} / d x
$$


and, disregarding the comparatively small net shear across the layer, slow viscous flow requires

$$
q_{w}=-\frac{\rho w^{h^{3}}}{12 n_{w}} \frac{\partial p_{w}}{\partial x}
$$

(Batchelor, 1967, p. 220), where $w_{n}(x)$ is the outward component of the basal ice velocity perpendicular to the liquid layer (Nye, 1969, p. 448) and $n_{w}$ is the viscosity of the water in the layer. Substitution of Equation (1a) into Equation (6a) and of the perturbation expansions for $p$ and $h^{-\alpha}$ into the result leads to

$q_{w}=-\frac{\rho_{w} h_{m}{ }^{3} \varepsilon}{1 \sigma_{w}}\left[\frac{d p_{1}}{d x}-\left(\frac{\rho_{w}}{\rho_{i}}-1\right) \frac{b h_{m}{ }^{-\alpha}}{c} \frac{d \delta_{1}}{d x}\right]$

to first order in $\varepsilon$. The second term in the square brackets represents a pressure gradient that causes flow toward regions of smaller liquid-layer thickness. Fourier transformation of Equations (5) and

(6b) then gives

$$
\rho_{i} \bar{w}_{n}(k)=-i k \bar{q}_{w}(k)
$$

and

$\bar{q}_{w}(k)=-\frac{i k_{\rho_{w}} h_{m}{ }^{3} \varepsilon}{12 n_{w}}\left[\bar{p}_{1}(k)-\left(\frac{\rho_{w}}{\rho_{i}}-1\right) \frac{b h_{m}{ }^{-\alpha}}{c} \bar{\delta}_{1}(k)\right]$,

from which, as $\bar{w}_{n}(k)=\varepsilon W(k)$ (Nye, 1969, p. 450),

$\bar{p}_{1}(k)=-\frac{12 \rho_{i} n_{w} \bar{W}(k)}{\rho_{w} h_{m}^{3} k^{2}}+\left(\frac{\rho_{w}}{\rho_{i}}-1\right) \frac{b h_{m}-\alpha_{\bar{\delta}}(k)}{c}$

on $z=0$.

Nye's relationship for the perturbed ice flow (1969, p. 452, eq. 24) remains unchanged, namely,

$$
\bar{p}_{1}(k)=z_{i}|k|[i k U \bar{f}(k)+\bar{W}(k)]
$$

on $z=0$, where $n_{i}$ is the viscosity of the basal ice, assumed Newtonian but with value dependent upon the basal effective shear stress, $U$ is the speed of sliding, and $z=\varepsilon f(x)$ is the profile of the bed. Simultaneous solution of Equations $(4),(8)$, and

(9) gives finally

$\bar{p}_{j}(k)=\frac{2 i \operatorname{nij}_{j} U \bar{f}(k) k|k|\left(k_{0}{ }^{3}+k_{1}{ }^{2}|k|\right)}{k_{0}{ }^{3}+k_{1}{ }^{2}|k|+|k|^{3}}$,

$\bar{W}(k)=-\frac{i U \bar{f}(k) k^{3}|k|}{k_{0}^{3}+k_{1}{ }^{2}|k|+|k|^{3}}$,

$\bar{\delta}_{1}(k)=-\frac{c}{b h_{m}{ }^{-\alpha}} \frac{2 \operatorname{in} j u \bar{f}(k) k|k|}{k_{0}{ }^{3}+k_{1}{ }^{2}|k|+|k|^{3}}$

$$
\left[\begin{array}{cc}
k_{0}{ }^{3}-k_{1}^{2} & |k| /\left(\frac{\rho_{W}}{\rho_{i}}-1\right)
\end{array}\right] \text {, }
$$

in which

$k_{0}{ }^{3}=\frac{6 \rho_{i}{ }^{2} n_{w}}{\rho_{w}{ }^{2} n_{i} h_{m}{ }^{3}}, \quad k_{1}{ }^{2}=\frac{L}{4 C k_{n}} i\left(1-\frac{\rho_{i}}{\rho_{w}}\right)$.
With $\bar{p}_{1}(k)$ given by Equation (10a), Nye's formula for the drag (1970, p. 385, eq. 5) becomes

$\left\langle\tau_{x y}\right\rangle=\frac{2 \pi j U}{\pi} \int_{0}^{\infty} S_{b}(k) \frac{k_{0}{ }^{3}+k_{1}{ }^{2} k}{k_{0}{ }^{3}+k_{1}{ }^{2} k+k^{3}} k^{3} d k$,

where $S_{b}(k)$ is the spectral power density of the glacier bed profile. Because $k_{0}$ and $k$ are both positive, the denominator is positive throughout the range of integration, by Descartes's rule of signs. Taking

$S_{b}(k)=\left\{\begin{array}{cl}a k^{-3}, & k \geqslant k \\ 0, & k<k\end{array}\right.$

(Nye, 1970, p. 386-387), where $2 \pi / k$ is to be chosen much larger than the distance over which the running mean is taken in obtaining the datum from which the bed profile is measured (Nye, 1970, p. 387), the drag is

$$
\left\langle\tau_{x y}\right\rangle=\frac{2 n_{j} \cup a}{\pi} \int_{k}^{\infty} \frac{k_{0}{ }^{3}+k_{1}{ }^{2} k}{k_{0}{ }^{3}+k_{1}{ }^{2} k+k^{3}} d k \text {. }
$$

Calculation of sliding speeds

Table I gives the data and their sources used in

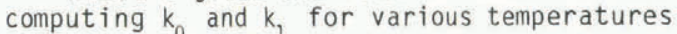

$\Delta \theta=\theta-\theta p M+C\left(p^{1}-p P M\right)$ relative to the nominal pressure-melting point of pure water. Treating the temperature in this way eliminates from explicit consideration the average pressure due to the weight of the overlying ice. For $\Delta \theta$ in the range from $-10^{-8}$ to $-20^{\circ} \mathrm{C}$ the term involving $\mathrm{k}^{2}$ in the denominator of the integrand in Equation (13) is negligible compared to the sum of the other two terms. Omitting this term, performing the integration, and dropping terms negligible because $k$ and $k_{1}$ are small compared to $k_{0}$, leads to

$$
\left\langle\tau_{x y}\right\rangle=\frac{4}{9} 3^{\frac{1}{2}} n_{j} U k_{0} a .
$$

Figure 1 shows the sliding speeds computed from this formula for $a=0.022$ and drag and basal effective stress both $100 \mathrm{kPa}$ (1 bar).

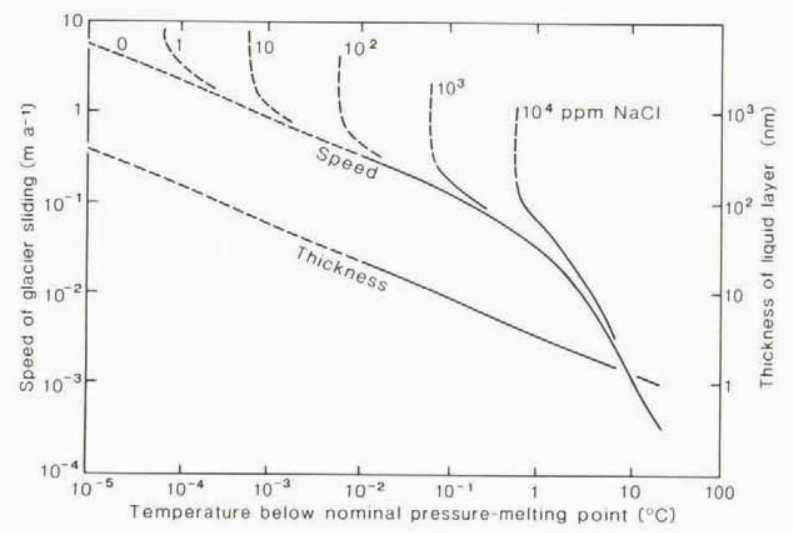

Fig. 1. Speed of glacier sliding and thickness of liquid layer as functions of temperature of basal ice for various average solute concentrations in liquid layer. Temperature is relative to nominal pressure-melting point of pure water. Dashed portions of curves based on extrapolation of Gilpin's ( $1980, p .445)$ data toward the pressure-melting point. Speeds calculated for drag and basal effective stress both $100 \mathrm{kPa}(1 \mathrm{bar})$ and bed roughness spectrum as measured by Nye (1970, p. 386-387). 


\begin{tabular}{|c|c|c|c|c|c|c|c|c|c|c|}
\hline$\Delta \theta^{(1)}$ & $n_{m}(2)$ & $n_{w}(3)$ & $\rho_{W}{ }^{(4)}$ & $n_{i}(5)$ & $\rho_{i}{ }^{(6)}$ & $K(7)$ & $L^{(8)}$ & $c^{(9)}$ & $M(10)$ & ${ }_{D}(11)$ \\
\hline${ }^{\circ} \mathrm{C}$ & $\mathrm{nm}$ & $\mathrm{mPa} \mathrm{s}$ & $\mathrm{kg} \mathrm{m}^{-3}$ & $\mathrm{kPa} a$ & $\mathrm{~kg} \mathrm{~m}^{-3}$ & $\mathrm{KJ} \mathrm{m}^{-1} \mathrm{~s}^{-1}{ }^{\circ} \mathrm{C}^{-1}$ & Mu $m^{-3}$ & ${ }^{\circ} \mathrm{C} \mathrm{MPa}^{-1}$ & $m^{\circ} \mathrm{C}$ p.p.m. ${ }^{-1}$ & $\mathrm{~mm}^{2} \mathrm{~s}^{-1}$ \\
\hline $\begin{array}{l}-10^{-8} \\
-10^{-5} \\
-0.01 \\
-0.1 \\
-1 . \\
-2 . \\
-5 . \\
-10 . \\
-20 .(12)\end{array}$ & $\begin{array}{r}7500 \\
420 \\
23.7 \\
9.1 \\
3.5 \\
2.6 \\
1.8 \\
1.3 \\
1.0\end{array}$ & $\begin{array}{l}(1.79) \\
(1.79) \\
(1.79) \\
(1.80) \\
1.86 \\
1.93 \\
2.16 \\
2.66 \\
4.33\end{array}$ & $\begin{array}{r}1000 \\
1000 \\
1000 \\
1000 \\
1000 \\
1000 \\
1000 \\
1000 \\
990\end{array}$ & $\begin{array}{r}17 \\
17 \\
17 \\
18 \\
31 \\
56 \\
240 \\
1000 \\
3000\end{array}$ & $\begin{array}{l}920 \\
920 \\
920 \\
920 \\
920 \\
920 \\
920 \\
920 \\
920\end{array}$ & $\begin{array}{l}(2.24) \\
(2.24) \\
(2.24) \\
2.24) \\
(2.25) \\
(2.26) \\
(2.28) \\
2.32 \\
2.43\end{array}$ & $\begin{array}{l}(306) \\
(306) \\
(306) \\
305) \\
(301) \\
(297) \\
283 \\
262 \\
222\end{array}$ & $\begin{array}{c}(0.074) \\
(0.074) \\
(0.074) \\
0.074) \\
(0.075) \\
(0.075) \\
0.079 \\
0.083 \\
0.092\end{array}$ & $\begin{array}{l}(0.06) \\
(0.06) \\
(0.06) \\
0.06) \\
(0.06) \\
(0.06) \\
(0.07) \\
(0.07) \\
(0.09)\end{array}$ & $\begin{array}{l}(0.0014) \\
(0.0014) \\
(0.0014) \\
(0.0014) \\
(0.0014) \\
(0.0014) \\
(0.0014) \\
(0.0013) \\
(0.0013)\end{array}$ \\
\hline
\end{tabular}

(1) Temperature relative to nominal pressure-melting point of pure water.

(2) Computed from (1b).

(3) Hallett (1963, p. 1049); values in parentheses interpolated.

(4) Hallett (1963, p. 1048).

(5) For effective stress $\tau$ of $100 \mathrm{kPa}$ (1 bar); varies inversely as square of effective stress; computed from formula $\eta_{j}=1 /\left\{n A \exp \left[B_{A} \Delta s-\left(Q+B B_{0} s\right) / R T \tau^{n-1}\right\}\right.$ with $A=2.684 \times 10^{4} \mathrm{kPa}^{-3} a^{-1}$, $Q=60 \mathrm{KJ} \mathrm{mol}^{-1}, R=8.314 \mathrm{~J} \mathrm{~mol}^{-1} \mathrm{~K}^{-1}, T=\Delta \Theta+M c_{m}+273.1$, approximately, $\Delta \mathrm{s}=1 / 263.1-1 / T$, $n=3, B_{A}=5.1294 \times 10^{5} \mathrm{~K}, B_{0}=1.114 \times 10^{-6} \mathrm{~kJ} \mathrm{~K} \mathrm{~mol}^{-1}$ for $\Delta \theta$ warmer than $-10^{\circ} \mathrm{C}, \mathrm{B}_{\mathrm{A}}=0, \mathrm{~B}_{0}=0$, otherwise; based on discussion by Paterson (1981, p. 26, 27, 28, 34-40) plus assumption that viscosity is $100 \mathrm{kPa}\left(1 \mathrm{bar}\right.$ a) at $0^{\circ} \mathrm{C}$ and $100 \mathrm{kPa}$ (1 bar) effective stress.

(6) Dorsey (1940, p. 466, 469).

(7) Dorsey (1940, p. 482); values in parentheses interpolated, thermal conductivity of rock assumed same as for ice.

(8) Dorsey (1940, p. 617); values in parentheses interpolated.

(9) Computed from $L, \rho_{W}$, and $\rho_{i}$.

(10) $\mathrm{NaCl}$; Kaufmann (1960, p. 613); values in parentheses corrected for temperature using equation 36.5 of Glasstone (1947, p. 340) for dilute solutions.

(11) $\mathrm{NaCl}$; Harned and Owen (1958, p. 255); values in parentheses corrected for temperature using equation 4-4-11 (p. 120) for dilute solutions.

(12) Thermodynamic data not available for temperatures below $-22^{\circ} \mathrm{C}$, the triple-point temperature of bulk water, ice-I, and ice-III.

The value $a=0.022$ was computed by Nye (1970, p. 388-389) from a profile measured near the terminus of Austerdalsbreen, Norway, in 1963 using the formula

$a=4 \pi r^{2} / 0.148$,

where $r=0.016$ is the root-mean-square deviation of the profile from its simple centered running mean over distances of the order of $100 \mathrm{~m}$ (Nye, 1970, p. $385,389)$. It may not be accurate for wavelengths $2 \pi / k$ less than a few millimeters (Nye, 1970, p. 387). Equation (14) is not valid above about $-10^{-8}{ }^{\circ} \mathrm{C}$, because $k_{0}$ is not large compared to $k_{1}$ at the higher temperatures. This is because, as the thickness of the liquid layer exceeds about $10 \mu \mathrm{m}$, the flow of heat through the basal ice and the glacier bed, rather than the flow of water through the liquid layer, becomes the rate-limiting factor in the regelation process. This transition thickness is an order of magnitude greater than expected from Nye's theory (1973[b], p. 190), even though the important wavelengths, which are about one metre, and hence the geometry of heat and ice flow, are comparable in the two theories. The discrepancy is due to the fact that in the modified theory the gradient in pressure from stoss to lee of obstacles caused by shearing of the ice over the bed is partially offset by an opposing gradient caused by the smaller thickness of the liquid layer on the stoss side.

As al ready noted, it is necessary that $\delta_{1}, \delta_{2}, \ldots$, in Equation (3) be small relative to $1 / \varepsilon$. For drag and temperature externally fixed, as would normally be the case, this requirement sets a non-zero lower limit on $\varepsilon$ in addition to the upper limit $\varepsilon \ll<$. Equations (14) and (15) show that halving $\varepsilon$, and therefore $r$, for example, will quarter a and quadruple U; Equation (10c) shows that this in turn wil quadruple $\delta_{1}$. Thus, as $\varepsilon$ decreases, $1 / \varepsilon$ increases more slowly than $\delta_{1} ;$ hence, the condition $\delta_{1} \ll 1 / \varepsilon$ cannot hold for sufficiently small $\varepsilon$.

To make this more quantitative requires an estimate of $\delta_{1}$, which requires inverse transformation of Equation $(10 c)$. This in turn cannot be done without more information about $f(x)$ or $\bar{f}(k)$ than is given by the spectral power density, Equation (12b). A conservative over-estimate can be made, however, by replacing with its maximum the function of $k$ multiplying $f(k)$ in Equation (10c) and performing the inverse transformation.

Before doing so it is necessary to put Equation (10c) in terms of $\bar{f}^{\prime}(k)=-i k \bar{f}(k)$, the transform of $f^{\prime}(x)=d f / d x$, because $\left|f^{\prime}(x)\right|$ is of order 1 , inasmuch as $\varepsilon$ approximates the slopes of the bed roughness whereas $|f(x)|$ has no particular order of magnitude, inasmuch as it is a dimensional quantity.

Making this change, dropping negligible terms involving $k_{1}$, solving for the maximum, which occurs for $|k|^{3}=\left|k_{0}\right|^{3} / 2$, performing the inverse transformation, eliminating $n_{j} U k_{0}$ and a by means of Equations (14) and (15), substituting $|\Delta \theta|$ for $\mathrm{bh}_{\mathrm{m}}{ }^{-\alpha}$, and setting $\left|\delta_{1}\right| \max \ll<1 / \varepsilon$ leads finally to

$0.016 C\langle\tau x y\rangle /|\Delta \theta|\langle<\varepsilon<1$.

as the conservative minimum permissible range of $\varepsilon$. For $\langle\tau, x y\rangle=100 \mathrm{kPa}(1 \mathrm{bar})$ the lower limit in Equation (16) varies from 0.01 to 0.1 as $|\Delta \theta|$ decreases from approximately 0.1 to $0.002^{\circ} \mathrm{C}$.

\section{DISSOLVED SOLUTES}

\section{Modification of present theory}

Because the thickness of the liquid layer is very nearly uniform, the theory is easily modified to take 
into approximate account the presence of dissolved solutes.

Assuming that the solute is not influenced by the presence of the foreign solid, as seems likely for the dissolved air and various ions most likely to be present, Equation (1a) remains unchanged and the right-hand side of Equation (1b) has an additional term $-M c$, where $M$ is the rate of decrease of melting temperature with solute concentration $c$, assumed dilute. Hence, the right-hand side of Equation (2) also has an additional term $-M\left(c-c_{m}\right)$, where $c_{m}$ is the value of $c$ averaged over the glacier bed and is considered to be known. In terins of the small bed-perturbation parameter $\varepsilon$,

$c=c_{m}\left(1+\varepsilon \gamma_{1}+\varepsilon^{2} \gamma_{2}+\ldots\right)$.

Thus, the right-hand side of Equation (4) has an additional term $-M c_{m} \bar{Y}_{1}(k) / C$. Equations (8) and (9) have no additional terms, however, because their derivation does not involve Equation (1b). In addition, $h_{m}$ in Equations (2), (4), and ( 8 ) becomes $h_{m *}$ as a reminder that it is to be computed from the modified Equation (1b) using the average solute concentration $\mathrm{c}_{\mathrm{m}}$.

The advection of the solute by the flow in the liquid layer is balanced by diffusion in the opposite direction, so that

$$
h D d c / d x=q_{w} c / \rho_{w},
$$

approximately, assuming partitioning of the solute entirely to the liquid and letting $D$ be the diffusivity of the solute. Substitution of the perturbation expansions, Equation (3) and (17), followed by Fourier transformation and substitution of $\varepsilon \bar{W}(k)$ for

$w_{n}(k)$, as before, then gives

$$
\bar{r}_{1}(k)=\frac{\rho_{i} W(k)}{\rho_{W^{D}} D h_{m *} k^{2}} \text {. }
$$

Simultaneous solution of the modified equations gives the same expressions as before for $\bar{p}_{1}(k)$ and $\bar{W}(k)$, Equations (10a) and (10b), and hence for the drag, Equations (12), (13), and (14), provided $k_{0}{ }^{3}$ is replaced by

$k_{0 *}{ }^{3}=\frac{6 \rho_{i}{ }^{2} n_{w}}{\rho_{w}{ }^{2} n_{i} h_{m *}{ }^{3}}+\frac{\rho_{j} M c_{m}}{2 \rho_{w} n_{i} C C_{m} n_{m}}\left(1-\frac{\rho_{i}}{\rho_{w}}\right)$.

For $\bar{\delta}_{1}(k)$ the expression is as in Equation (10c) with $h_{m}$ and $k_{0}$ replaced by $h_{m *}$ and $k_{0 *}$ and a term

$$
-\frac{\rho_{i} \mathrm{MC}_{\mathrm{m}}}{2 p_{w^{n}}{ }_{j} \mathrm{CDh}_{\mathrm{m}}}
$$

added inside the square brackets. Finally, from Equations (10b) and (19)

$$
\bar{r}_{1}(k)=-\frac{\rho i}{\rho_{w} D_{m *}} \quad \frac{i \cup \tilde{f}(k) k|k|}{k_{0 *}{ }^{3}+k_{1}{ }^{2}|k|+|k|^{3}} .
$$

\section{Effect on sliding speeds}

Table I gives the additional data and their sources used in computing $k_{\text {* }}$; and Figure 1 shows the sliding speeds computed from Equations (14) and (20) for various average concentrations of $\mathrm{NaCl}$ in the 1 iquid layer as functions of the temperature below the nominal pressure melting point of pure water. In the range of validity of Equation (14) ( $k$ and $k_{1}$ small compared to $k_{0}$ ), the presence of the solute increases the speed of sliding because it increases the thickness of the liquid layer, and hence the flow of water, without significantly affecting the temperatures of melting and freezing, and hence the flow of heat, which is exactly the opposite of its effect in Nye's theory (as modified by Hallet, 1976[b], p. 213).

With solute present it is necessary that both $\delta_{1}$ and $\gamma_{1}$ be small relative to $1 / \varepsilon$. Applying the procedure used to derive Equation (16) to the modified Equations (10c) and (21) yields

$0.016 C\left\langle\tau_{x y}>\max (\phi, 1) / G \ll \varepsilon \ll 1\right.$

as the conservative minimum permissible range of $\varepsilon$, where

$$
\begin{aligned}
& G=\frac{12 \rho j^{n} W^{C D}\left|\Delta \theta_{*}\right|^{2 / \alpha}}{\rho_{W^{b^{2 / \alpha}}}}+M c_{m}\left(1-\frac{\rho_{i}}{\rho_{w}}\right), \\
& \phi=\frac{1}{\left|\Delta \theta_{*}\right|} \frac{12 \rho_{i}{ }^{n} w^{C D}\left|\Delta \theta_{\star}\right|^{2 / \alpha}}{\rho_{w} b^{2 / \alpha}}-\frac{\rho_{i}}{\rho_{W}} M c_{m},
\end{aligned}
$$

and

$$
\left|\Delta \theta_{*}\right|=|\Delta \theta|-M c_{m},
$$

which is the temperature measured downward from the nominal pressure-melting point of a solution of concentration $c_{m}$.

For $\langle\tau x y\rangle=100 \mathrm{kPa}(1 \mathrm{bar})$ and $c_{m}=1$ p.p.m. the lower limit in Equation (22a) varies from 0.01 to 0.1 as $\left|\Delta \theta_{*}\right|$ decreases from approximately. 0.1 to $0.002^{\circ} \mathrm{C}$. The corresponding range for $c_{m}=10^{4}$ p.p.m. is approximately 0.1 to $0.005^{\circ} \mathrm{C}$.

\section{DISCUSSION}

Sliding at sub-freezing temperatures

Figure 1 indicates that the basal sliding speeds of typical subfreezing glaciers will be extremely low, and it shows why the direct field observations failed to detect sliding. The effect of such low speeds on glacier motion will be completely negligible. The total distance of sliding during the lifetimes of large glaciers, on the other hand, can be of consequence. In $10^{5}$ a, for instance, it ranges from roughly $35 \mathrm{~m}$ at $-20^{\circ} \mathrm{C}$ to roughly $350 \mathrm{~m}$ at $-5^{\circ} \mathrm{C}$ for drag and basal effective stress both $100 \mathrm{kPa}$ ( 1 bar) and would be five times as great at $200 \mathrm{kPa}$ ( $2 \mathrm{bar})$, inasmuch as the sliding speed increases as the stress raised to the power $7 / 3$. Assuming that rocky debris was incorporated into the basal ice when the glacier initially began accumulating, the formation of bedrock striations, though not of grooves, seems highly plausible. In addition, the formation of subglacial carbonate or other coatings on suitable bedrock, as described by Hallet $(1975 ; 1976[a])$ for temperate glaciers, is not precluded. Thus, neither striations nor coatings necessarily indicate temperate ice. If coatings form, the largest rock fragments in them, if any are present, should be very much smaller than those observed by Hallet (1979, p. 325-326). If observable, they might permit rough estimation of the liquid-layer thickness and hence of the basal ice temperature.

The maximum contribution to the drag comes from the logarithmic wave-number interval d( $\mathrm{nn} k$ ) located at $k=k_{0} / 2^{1 / 3}=0.749 k_{0}$. Imposing low- and highfrequency cut-offs on the bed spectrum in Equation (13), as done by Nye $(1970$, p. 391$)$, shows that $90 \%$ of the drag comes from that part of the spectrum between $9 k_{0}$ and $k_{0} / 9$, which at temperatures below about $-1{ }^{\circ} \mathrm{C}$ corresponds to wavelengths of 0.1 to $10 \mathrm{~mm}$ for basal effective stress $100 \mathrm{kPa}$ ( 1 bar) and 
solute concentrations from 0 to $10^{4}$ p.p.m. These wavelengths vary inversely as the basal effective stress, raised to the power $2 / 3$, in accordance with Equation (11) and the formulae of note (5) of Table I. In any case, they are small enough that the value of a used in computing the sliding speeds plotted in Figure 1 may be inaccurate.

\section{sliding with net melting}

Equation (1b) implies that the liquid layer can never be at the nominal pressure-melting temperature even in a temperate glacier, because it can never be infinitely thick. Instead, it will be at some lower temperature corresponding to its actual thickness, the ambient pressure, and the solute concentration. How this temperature is governed depends upon whether more basal ice melts into the liquid layer than refreezes, that is, whether there is net melting. With no net melting the temperature is governed by the temperature of the ice above and the rock below, and the thickness adjusts accordingly. With net melting, on the other hand, the thickness is governed by the rate of escape of the excess water, and it is the temperature that adjusts accordingly. Thus, the proper distinction is not between temperate and cold, which in this context are meaningless, but between net melting and no net melting.

With net melting the liquid-layer thickness and, concomitantly, the temperature and the sliding speed increase until the rate of escape balances the rate of melting. The ease of escape is governed by the proximity of subglacial water passages (like those considered by Lliboutry, 1968, p. 54-56; Röthlisberger 1972, p. 200-201; Shreve, 1972, p. 211-213; Weertman, 1972, p. 291-308; and Nye, 1973[b], p. 191-192) and by the pressures in them, and is likely to be highly variable from case to case. No conflict such as discussed by Nye (1973[b]) arises between the thickness requirement for run-off water flow and that for regelation water flow, although the thickness may become so great that $k$ is not negligible or the perturbation method of solving the equations becomes inapplicable. The theory thus applies whether or not there is net melting.

\section{ACKNOWLEDGEMENTS}

I thank William M. Bruner and Bernard Hallet for discussions and information that greatly aided my thinking about subglacial conditions and processes. This paper is based upon work supported by the U.S. National Science Foundation under Grant No. EAR8121051. It is publication No. 2441 of the Institute of Geophysics and Planetary Physics, University of Cal ifornia, Los Angeles.

\section{REFERENCES}

Barer, S.S., and others. 1977. Tolshchina i vyazkost tonkikh nezamerzayushchikh prozloyek mezhdu poverkhnostyami l'da i kvartsa [Thickness and viscosity of thin unfrozen layers between ice and quartz]. [By] S.S. Barer, V.I. Kvlividze,

A.B. Kurzayev, V.D. Sobolev, N.V. Churayev. Doklady Akademii Nauk SSSR, Tom 235, No. 3, p. 601-03. [Translated in Doklady Physical Chemistry, Vol. 235, No. 3, 1977, p. 701-04.

Batchelor, G.K. 1967. An introduction to fluid dynamics. London, Cambridge University Press.

Dorsey, N.E. 1940. Properties of ordinary watersubstance in all its phases: water-vapor, water, and all the ices. New York, Reinhold Publishing Corporation. (American Chemical Society. Monograph Series, No. 81.) [Facsimile, New York, Hafner Publishing Co., 1968.]

Drake, L.D, and Shreve, R.L. 1973. Pressure melting and regelation of ice by round wires. Proceedings of the Royal Society of London, Ser. A, Vol. 332, No. 1588, p. 51-83.
Faraday, M. 1850. On certain conditions of freezing water; or, on the philosophy of water and ice. Lecture at Royal Institution of Great Britain, London, 7 June 1850. [Unsigned abstract by Faraday published in The Athenaeum, No. 1181, 15 June 1850, p. 640-41. Manuscript notes at Royal Institution, according to Jeffreys (1960, p. 50, ref. 383).]

Fletcher, N.H. 1962. Surface structure of water and ice. Philosophical Magazine, Eighth Ser., Vol. 7 , No. 74, p. 255-69.

Gilpin, R.R. 1979. A model of the "liquid-like" layer between ice and a substrate with applications to wire regelation and particle migration. Journal of colloid and Interface science, Vol. 68, No. 2, p. 235-51.

Gilpin, R.R. 1980. Wire regelation at low temperatures. Journal of colloid and Interface science, Vol. 77 , No. 2, p. 435-48.

Glasstone, S. [C'1947]. Thermodynamics for chemists. Princeton, New Jersey, D. Van Nostrand Co. Inc.

Goldthwait, R.P. 1960. Study of ice cliff in Nunatarssuaq, Greenland. U.S. Snow, Ice and Permafrost Research Establishment. Technical Report 39.

Hallet, B. 1975. Subglacial silica deposits. Nature, Vul. 254, No. 5502, p. 682-83.

Hallet, B. 1976[a]. Deposits formed by subglacial precipitation of $\mathrm{CaCO}_{3}$. Geological Society of America. Bulletin, Vol. 87, No. 7, p. 1003-15.

Hallet, B. 1976[b]. The effect of subglacial chemical processes on glacier sliding. Journal of Glaciology, Vol. 17, No. 76, p. 209-21.

Hallet, B. 1979. Subglacial regelation water film. Journal of Glaciology, Vol. 23, No. 89, p. 321-34.

Hallett, J. 1963. The temperature dependence of the viscosity of supercooled water. Proceedings of the Physical Society (London), Vol. 82, Pt. 6, p. 104650 .

Harned, H.S., and Owen, B.B. 1958. The physical chemistry of electrolytic solutions. Third edition. New York, Reinhold Publishing Corporation. (American Chemical Society. Monograph Series, No. 137.)

Hilty, R.E. 1960. Appendix. Supplementary glacial studies, 1957. (In Goldthwait (1960, p. A1-A14).)

Hoekstra, P., and Miller, R.D. 1967. On the mobility of water molecules in the transition layer between ice and a solid surface. Journal of colloid and Interface science, Vol. 25, No. 2, p. 166-73.

Holdsworth, G., and Bull, C.B.B. 1970. The flow law of cold ice; investigations on Meserve Glacier, Antarctica. [Union Géodésique et Géophysique Internationale. Association Internationale d'Hydrologie scientifique.] [International council of scientific Unions. Scientific Committee on Antarctic Research. International Association of Scientific Hydrology. Commission of Snow and Ice.] International Symposium on Antarctic Glaciological Exploration (ISAGE), Hanover, New Hampshire, U.S.A., 3-7 September 1968, p. 204-16. [(Publication No. 86 [de 1'Association Internationale d'Hydrologie Scientifique].)]

Jeffreys, A.E. 1960. Michael Faraday, a list of his lectures and published writings. London, Chapman and $\mathrm{Hall}$.

Jellinek, H.H.G. 1967. Liquid-like (transition) layer on ice. Joumal of colloid and Interface science, Vol. 25, No. 2, p. 192-205.

Kamb, W.B. 1970. Sliding motion of glaciers: theory and observation. Reviews of Geophysics and Space Physics, Vol. 8, No. 4, p. 673-728.

Kaufmann, D.W., ed. 1960. Sodium chloride, the production and properties of salt and brine. New York, Reinhold Publishing Corporation. (American Chemical Society. Monograph Series, No. 145.)

Lliboutry, L.A. 1968. General theory of subglacial cavitation and sliding of temperate glaciers. Journal of Glaciology, Vol. 7, No. 49, p. 21-58.

Mellor, M., and Testa, R. 1969. Effect of temperature on the creep of ice. Journal of Glaciology, Vol. 8, No. 52, p. 131-45. 
Nakaya, U., and Matsumoto, A. 1953. Evidence of the existence of a liquid-like film on ice surfaces. U.S. Snow, Ice and Permafrost Research Establishment. Research Report 4.

Nye, J.F. 1969. A calculation on the sliding of ice over a wavy surface using a Newtonian viscous approximation. Proceedings of the Royal Society of London, Ser. A, Vol. 311, No. 1506, p. 445-67.

Nye, J.F. 1970. Glacier sliding without cavitation in a linear viscous approximation. Proceedings of the Royal Society of London, Ser. A, Vol. 315, No. 1522, p. 381-403.

Nye, J.F. 1973[a]. The motion of ice past obstacles. (In Whalley, E., and others, ed. Physics and chemistry of ice: papers presented at the Symposium on the Physics and Chemistry of Ice, held in Ottawa, Canada, 14-18 August 1972. Edited by E. Whalley, S.J. Jones, L.W. Gold. Ottawa, Royal Society of Canada, p. 387-94.)

Nye, J.F. 1973[b]. Water at the bed of a glacier. Union Géodésique et Géophysique Internationale. Association Internationale d'Hydrologie Scientifique. Commission de Neiges et Glaces. Symposium on the Hydrology of Glaciers, Cambridge, ?-13 september 1969, p. 189-94. (Publication No. 95 de 1'Association Internationale d'Hydrologie Scientifique.)
Paterson, W.S.B. 1981. The physics of glaciers. Second edition. Oxford, etc., Pergamon Press. (Pergamon International Library.)

Römkens, M.J.M., and Miller, R.D. 1973. Migration of mineral particles in ice with a temperature gradient. Journal of Colloid and Interface Science, Vol. 42, No. 1, p. 103-11.

Röthl isberger, H. 1972. Water pressure in intra- and subglacial channels. Journal of Glaciology, Vol. 11 , No. 62, p. 177-203.

Shreve, R.L. 1972. Movement of water in glaciers. Journal of Glaciology, Vol. 11, No. 62, p. 205-14.

Telford, J.W., and Turner, J.S. 1963. The motion of a wire through ice. Philosophical Magazine, Eighth Ser., Vol. 8, No. 87, p. 527-31.

Weertman, J. 1957. On the sliding of glaciers. Journat of Glaciology, Vol. 3, No. 21, p. 33-38.

Weertman, J. 1964. The theory of glacier sliding. Journal of Glaciology, Vol. 5, No. 39, p. 287-303. Weertman, J. 1972. General theory of water flow at the base of a glacier or ice sheet. Reviews of Geophysics and Space Physics, Vol. 10, No. 1, p. 287333.

Weyl, W.A. 1951. Surface structure of water and some of its physical and chemical manifestations. Journal of Colloid science, Vol. 6, No. 5, p. 389-405. 